\title{
Factors inducing fertility in aseptic Crustacea*
}

\author{
L. Provasoli, D. E. Conklin and A. S. D’Agostino \\ Haskins Laboratories, New York and St. Jobn's University; Jamaica, N.Y., USA
}

KURZFASSUNG: Faktoren, die Fertilität bei keimfrei gezüchteten Crustaceen induzieren. Nur die kontinuierliche Kultivierung eines Organismus gewährt Sicherheit, daß alle ernährungsphysiologischen und kulturtechnischen Erfordernisse erfüllt worden sind. Keimfreie Zuchten yon Insekten und Krebsen zeigen, daß die Voraussetzungen für eine uneingeschränkte Fertilität komplexer sind als für die Produktion einer oder mehrerer sukzessiv aufeinanderfolgender Generationen. Ahnliche Ergebnisse sind mit aseptisch gehaltenen Artemia salina, Daphnia magna und Tigriopus japonicus erhalten worden. Die Schlußfolgerungen sind daher möglicherweise auch auf weitere Arten ausdehnbar. Nur in seltenen Fällen vermag eine Algenart alle ernährungsphysiologischen Erfordernisse des zu züchtenden Tieres zu erfüllen; oft werden zwei oder mehrere Algenarten benötigt. Jedoch selbst in diesen Fällen versiegt die Fertilität häufig nach einigen wenigen aseptischen Generationen. Bei $T$. japonicus kompensierte der Zusatz von Vitaminen die ernährungsphysiologische Unzulänglichkeit von 2 Futteralgen. Zugabe von einigen Milligramm Hefe und Leberextrakt zu dem Kulturmedium, in dem Algen und Krebse gehalten wurden, restaurierte die Fertilität von $A$. salina (die durch osmotischen Stress geschwächt waren) und gestattete eine kontinuierliche Kultur von $D$. magna in synthetischen Mineralmedien. Offensichtlich beeinflussen die organischen Anreicherungen nicht direkt die Ernährung von $D$. magna, sondern vielmehr den ernährungsphysiologischen Wert, welchen die Algen für $D$. magna besitzen. Qualität und Quantität der organischen Substanz in natürlichen Gewässern sind daher möglicherweise von Bedeutung für die Fertilität von Crustaceen. Die ernährungsphysiologischen Ansprüche von $A$. salina, D. magna und Moina macrocopa, welche aseptisch in künstlichen Medien kultiviert werden, sind sehr ähnlich. Alle Arten beanspruchen Cholesterin, Thiamin, Biotin, Phyridoxin und Nicotin-, Fol- und Pantothensäure zur Produktion von Adulti; es werden jedoch höchstens 1 oder 2 Generationen bei geringer Fruchtbarkeit erreicht. 6 Generationen von D. magna und 50 Generationen von M. macrocopa wurden erhalten, nachdem Eidotter und die Vitamine $\mathrm{E}$ und $\mathrm{D}$ zugesetzt worden waren; Carotin war inaktiv. Fettlösliche Wirkstoffe spielen sicher eine Rolle. Thre Identifikation wird gegenwärtig betrieben.

\section{INTRODUCTION}

Culturing marine Crustacea, even under bacterized and partly gnotobiotic conditions, is still an art. Mortality is high, few adults are obtained, sex ratios are often lopsided; copulation may not occur and offspring, when obtained, may be weak. Volume and perhaps type of container greatly influence viability of cultures, copulation and offspring production (Zillioux \& Wilson 1966, CorkeTt 1968). As also

* Aided in part by contract Nonr 4062 with the Office of Naval Research and research grant GB-12078 of the National Science Foundation. 
apparent, many, perhaps most, of the difficulties are nutritional: the same teratology occurred in germ-free gnotobiotic cultures and was traced to nutritional deficiencies (Provasoli et al. 1959).

Previous observations were confirmed and some guide posts emerged, strengthened by later work.

(1) Size of prey is important for filter-feeders; often it is the only discriminatory factor. Burns (1968) found that in Cladocera maximum size of particle ingested is related to body size of the predator.

(2) Once the prey is ingested the efficiency of the algae as food varies with its composition and the nutritional requirements of the predator. Obviously, only when composition and requirements match will growth proceed from new-borns to fertile adults.

Inadequacy can be due to nutritional deficiencies, to toxicity, or indigestibility. Prymnesium parvum and probably Cricosphaera elongata are toxic to Heteramoeba clara (Droop 1966); but of the two only P. parvum is toxic to Artemia salina which is also inhibited by several dinoflagellates including species nonpoisonous to fishes or mammals such as Gyrodinium cobnii. Conversely, the highly poisonous Gonyaulax tamarensis of the Bay of Fundy is bappily digested by the tintinnid Favella (NEEDLER 1949).

Incomplete digestion is frequent and often related to presence, thickness and composition of the cell wall of the algae: many cells of Stichococcus fragilis survive passage through the gut of Artemia salina (Gibor 1956). Digestibility may depend also on gut-retention time which is governed by ingestion rate. Ingestion rate increases with increasing number of particles until the particles reach a critical concentration, then it levels off no matter how dense the suspension (Calanus, MARSHall \& Orr 1955; Dapbnia, McMahon \& Rigler 1963). Revve (1963) found for Artemia salina a similar plateau but it depended on volume rather than particle number. This implies that ingestion is so regulated that the retention time is close to, but not less than, the digestion time needed for "normal" algal food, otherwise there would not be enough time for digestion and assimilation, i. e., the faster the intake, the worse the starvation.

(3) Only rarely does a single alga satisfy all the requirements of a predator (Monochrysis lutheri supported 27 aseptic generations of Tigriopus japonicus before being discontinued accidentally). Algae adequate for one predator may be inadequate for other predators; of the 19 algae tried on Tigriopus japonicus and Artemia salina only Tetraselmis maculata (= Platymonas no. 5), Isocbrysis galbana and Rbodomonas lens were adequate for both Crustacea (Provasoli et al. 1959).

Even algae belonging to the same genus differ in nutritional value (Daphnia, Lefèvre 1942; Artemia, Grbor 1956, Provasoli et al. 1959, D’Agostino \& Provasoli 1968). Predators in utilizing algae may be fastidious or versatile: the rotifer Philodina roseola utilizes only Chlorophyceae; Heteramoeba thrives only on many Volvocales and 3 diatoms (Droop 1966); Balanus on one chrysomonad and several diatoms (Moyse 1963); Calanus (Marshall \& Orr 1965), Artemia salina and Tigriopus japonicus utilize some green algae, diatoms, chrysomonads and cryptomonads; all the algae tested support growth of Oxyrrbis marina (Droop 1966). 
(4) Success in growing a few generations of a predator may be transitory: only continuous culture assures that all nutritional and cultural requirements have been met; this may be difficult to secure. Mortality, reduced size of adults, low fertility or impotence may intervene after a few fertile generations as in Tigriopus japonicus.

A varied diet has far better chance to meet the nutritional needs. Thus Rbodomonas lens and Isochrysis galbana, which singly supported respectively 5 and 9 flial generations, in combination sustained over 250 germ-free generations of Tigriopus japonicus in the last ten years, indicating that one species made good the deficiencies of the other. This is undoubtedly not an isolated case even though a few other combinations were unsatisfactory. Bacteria and other microorganisms supplement in nature, as well as in the laboratory, the shortcomings of the algae. Tetraselmis maculata, which alone supported only 7 aseptic generations of $T$. japonicus, in combination with the natural microflora allowed thriving cultures of $T$. japonicus for more than 15 years.

Since the deficiencies appeared after several aseptic generations it seemed improbable that gross imbalances of macronutrients were involved and a lack of micronutrients, perhaps growth factors, was suspected; the algae may synthesize or concentrate them but suboptimally. Various nutrients were added singly and in combination to the medium in which the algae and Tigriopus japonicus were growing when signs of reduced fertility appeared. A vitamin mixture restored normal fertility, at least for 4 generations, in $T$. japonicus when the food organism was either Isocbrysis galbana or Chroomonas sp. (Shiraishi \& Provasoli 1959).

This remained an isolated case until D'Agostino tested the ability of the amphigonic and parthenogenetic strains of Artemia salina to grow and reproduce at different salinities. Even though the 2 Dunaliella used as food were preconditioned to grow equally well at all salinities by repeated subcultures, the 2 strains of $A$. salina, when cultivated at salinities of $3 \%$ or lower, failed to develop adults or the adults were infertile. The addition of $0.5 \mathrm{mg} \%$ each of liver and yeast extract restored normal development and fertility (D'Agostino \& Provasoli 1968).

\section{RESULTS WITH DAPHNIA MAGNA}

Similar events happened when Daphnia magna was brought in axenic culture (D'Agostino \& Provasoly unpublished). According to the literature, several food organisms were suitable for $D$. magna; the main problem was to find an adequate synthetic mineral medium. The media used for continuous cultures of $D$. magna were waters from springs, aquaria, rivers, ponds, or tapwater. Similar difficulties beset cultivation of D. pulex: "biologically preconditioned water" was needed to sustain fertility (Taub \& Dollar 1968). The longest period of cultivation in a synthetic mineral medium (salt mixture W, WEsson 1932) of D. magna, fed yeast and Scenedesmus obliquus, lasted 32 generations (DEWEY \& PARKER 1964).

We selected Scenedesmus obliquus and Chlamydomonas reinhardi as food organisms for Daphnia magna since they had been successfully used alone or with addition of yeast and bacteria. Several types of dilute media for fresh-water algae were tried 
and various modifications of the more suitable ones resulted in the basal medium DM (Table 1) which supports good growth of the 2 algae and is harmless to $D$. magna. These trials were conducted under bacterized conditions and resulted in 30 healthy generations of $D$. magna, then the culture declined.

Table 1

Diaxenic media for Daphnia magna $(\mathrm{mg} / 100 \mathrm{ml})$

\begin{tabular}{|c|c|c|c|}
\hline Components & $\mathrm{DM}$ & $\mathrm{DM}_{2}$ & $\begin{array}{l}\text { enriched with } \\
1 \mathrm{ml} \mathrm{DA} / 10 \mathrm{ml}\end{array}$ \\
\hline $\mathrm{KCl}$ & 5.0 & 5.0 & \\
\hline $\mathrm{MgSO}_{4} \cdot 7 \mathrm{H}_{2} \mathrm{O}$ & 4.0 & 4.0 & 0.2 \\
\hline $\mathrm{CaCl}_{2} \cdot 6 \mathrm{H}_{2} \mathrm{O}$ & 11.0 & 11.0 & \\
\hline $\mathrm{K}_{2} \mathrm{HPO}_{4}$ & 0.6 & 0.6 & 0.2 \\
\hline $\mathrm{KH}_{2} \mathrm{PO}_{4}$ & 0.6 & 0.6 & \\
\hline $\mathrm{NaNO}_{3}$ & 5.0 & 5.0 & \\
\hline $\mathrm{Na}_{2} \mathrm{SiO}_{3} \cdot 9 \mathrm{H}_{2} \mathrm{O}$ & 2.0 & 2.0 & \\
\hline $\mathrm{Fe}$ (as Cl) & $50 \mu \mathrm{g}$ & $50 \mu \mathrm{g}$ & $20 \mu \mathrm{g}$ \\
\hline P Iİ metals* & $1.0 \mathrm{ml}$ & $1.0 \mathrm{ml}$ & \\
\hline $\mathrm{B}_{12}$ & & $0.1 \mu \mathrm{g}$ & \\
\hline Thiamine & & $10 \mu \mathrm{g}$ & \\
\hline Na3citrate $\cdot 2 \mathrm{H}_{2} \mathrm{O}$ & & & 0.2 \\
\hline Thiotone (Baltimore Biol. Lab.) & & & 6.0 \\
\hline Trypticase (B.B.L.) & & & 1.6 \\
\hline Yeast extract & & & 0.5 \\
\hline $\mathrm{pH}$ & 7.5 & 7.8 & 6.5 \\
\hline
\end{tabular}

Mindful of the previous experience with Artemia salina, a few new-born Daphnia magna were transferred to new media inoculated with Scenedesmus obliquus and Chlamydomonas reinhardi grown on the organic enriched medium DA*. Fertility was fully restored and maintained until the crude cultures were discontinued (about 60 generations). Whether the organic substances carried over with the inoculum, or the bacterial growth resulting from these additions, was the important factor has never been determined because, by then, a bacteria-free culture of $D$. magna had been established on the same medium and the same food organisms.

The technique was the same as that used at the outset for crude cultures: $10 \mathrm{ml}$ of basal medium DM in $20 \times 150 \mathrm{~mm}$ screw-cap tubes was inoculated with $0.5 \mathrm{ml}$ each of a rich culture of Scenedesmus obliquus and Chlamydomonas reinbardi grown in the same mineral medium (neither alga needs vitamins for growth); after one day a new-born Daphnia magna was inoculated. When it developed into a fertile female, a new generation was established by transferring the first new-born into a new tube similarly prepared (temperature $16^{\circ}-28^{\circ} \mathrm{C}$, continuous illumination about $150 \mathrm{ft}$. c., white fluorescent tubes).

* DA medium is medium A (of Table 2, p. 840, Provasoli \& Pintner 1953). Composition in $\mathrm{mg} / 100 \mathrm{ml}$ : Nascitrate $2 \mathrm{H}_{2} \mathrm{O} 2.0 ; \mathrm{MgSO}_{4} 7 \mathrm{H}_{2} \mathrm{O} 2.0 ; \mathrm{K}_{2} \mathrm{HPO}_{4} 2.0 ; \mathrm{Fe}$ (as $\mathrm{SO}_{4}$ ) 0.2; Thiopeptone (B.B. L.) 60.0; Trypticase (B. B. L.) 16.0; yeast extract (Difco) $5.0 ; \mathrm{pH}=6.5$. 
Under these germ-free conditions the fertility of Daphnia magna faltered at the 10 th generation and was restored by inoculating $0.5 \mathrm{ml}$ of each of the 2 algae grown in the "DA" medium. We are now (September 1969) at the 190th germ-free generation with no sign of infertility: mean generation time was 8.5 days, mean survival of fecund females 20 to 22 days; mean newborn production per female lifetime, 30 . For safety, we now employ as basal medium "DM." (Tab. 1).

Daphnia magna grown in $\mathrm{DM}_{2}$ and fed with the 2 algae also grown in $\mathrm{DM}_{2}$ cease to grow after 12 generations. Since the enrichment was added to the same medium used for growing the algae and the crustaceans, in the experiments with Tigriopus, Artemia and Daphnia it was not clear whether the enrichment acted directly on the crustaceans or via the algae. Circumstantial evidence indicated that the enrichment acts via the algae, i. e. the algae become more nutritious (see discussion in D'Agostino \& Provasoli 1968).

Proof that this is so was obtained with Dapbnia magna. The 2 algae were grown separately on agarized DA medium and on agarized mineral medium $\mathrm{DM}_{2}$. Taking care not to remove any pieces of agar, the algae were scraped off and resuspended

Table 2

Effect of vitamin enrichment. Number of naupli per female*

\begin{tabular}{|c|c|c|c|}
\hline Enrichments & $\underset{A}{\text { Experiment }}$ & $\underset{B}{\text { Experiment }}$ & $\underset{C^{* * *}}{\text { Experiment }}$ \\
\hline $\begin{array}{l}\text { No addition } \\
\mathrm{B}_{12} 0.05 \mu \mathrm{g}^{0} \% \\
\mathrm{~B}_{12} \quad 0.1 \mu \mathrm{g}^{0} \% \\
\mathrm{~B}_{12} \quad 0.2 \mu \mathrm{g}^{0} \%\end{array}$ & $\begin{array}{r}2 \\
18\end{array}$ & $\begin{array}{l}0.7 \\
8.3 \\
21 \\
19\end{array}$ & $\begin{array}{r}0 \\
26\end{array}$ \\
\hline $\begin{array}{l}\text { Thiamine } 25 \mu \mathrm{g}^{0} \% \\
\text { Thiamine } 50 \mu \mathrm{g}^{0} \% \\
\text { Thiamine } 100 \mu \mathrm{g}^{0} \%\end{array}$ & 4 & $\begin{array}{l}0 \\
4.5 \\
2.3\end{array}$ & 0 \\
\hline $\begin{array}{l}\text { Ca pantothenate } 12 \mu \mathrm{g} \% \\
\text { Ca pantothenate } 25 \mu \mathrm{g} \% \\
\text { Ca pantothenate } 50 \mu \mathrm{g} \%\end{array}$ & 0 & $\begin{array}{l}0 \\
0 \\
1.3\end{array}$ & 0 \\
\hline $\mathrm{B}_{12} 0.1 \mu \mathrm{g} \%+$ Thiamine $10 \mu \mathrm{g} \%$ & 20 & 23 & 23 \\
\hline $\mathrm{B}_{12} 0.1 \mu \mathrm{g} \%+\mathrm{Ca}$ pantothenate $25 \mu \mathrm{g} \%$ & 32 & 25 & 31 \\
\hline $\begin{array}{l}\mathrm{B}_{12}+\text { Thiamine }+ \text { Pantothenate } \\
* \text { Averages of } 2 \text { or } 3 \text { females. } \\
* \text { Algae grown separately on agar. }\end{array}$ & 44 & 33 & 45 \\
\hline
\end{tabular}

in DM medium and one new-born $D$. magna was added. All operations were aseptic; sterility of cultures was checked at each generation and algal food added when necessary. $D$. magna ceased to reproduce at the 12 th generation when fed on the algae grown on mineral medium; they continued to the 20th generation (the experiment was then discontinued) when fed on the 2 algae grown in the organic enriched DA medium - paralleling exactly what happened when the enrichment was added directly to the algae-crustacean culture. 
It was now certain that the organic enrichment, although not needed for growth (the food algae of Artemia salina and Dapbnia magna are photoautotrophic), enhances the value of the algae for the crustacea.

Once it was found that the results were the same with 2 methods, it was possible to abandon this time-consuming and unwieldy technique and resume experimentation with the usual technique of adding the enrichment directly to the medium in which the algae and crustaceans are grown. Fortunately, when the inoculum of the experimental media is Scenedesmus obliquus and Cblamydomonas reinbardi, grown serially on the completely mineral medium DM, a good differential in naupliar production was obtained between the no-addition and the various enrichments. Preliminary experiments indicated that vitamins might underlie the effect of the organic enrichment for Dapbnia magna: vitamin $B_{12}$ substantially increased the fertility of $D$. magna; the other vitamins had no or slight effect. Addition of thiamine or pantothenic acid to $B_{12}$ caused a slight increase in fertility (Table 2). These 3 vitamins in combination led to a fertility almost matching that obtained with the entire organic enrichment. These preliminary results on $D$. magna confirm the effect of vitamins on the fertility of Tigriopus species.

The finding that vitamins in waters may subtly regulate crustacean fertility may impart greater ecological importance to the organic content and vitamin exchanges in natural waters.

\section{FERTILITY IN ARTIFICIAL MEDIA}

The key to crustacean growth and fertility should obviously be sought with the tool of nutrition. Once the essential nutrients of several species of crustacea are known, it should be possible to assess the nutritional adequacy of phytoplankton organisms by chemical or microbiological assays of key nutrients. It might also be possible to trace the biochemical events taking place in phytoplankton species intervening between exposure to vitamins and formation of fertility-increasing substances for crustaceans.

After 10 years of work on the nutrition of Artemia salina, Dapbnia magna and, recently, Moina macrocopa, some common features emerge. An absolute dependence on phagotrophy is, in laboratory experiments, limited to bulk nutritional requirements (amino acids and carbohydrates); in the natural habitat these Crustacea are probably wholly phagotrophic. Artificial media for A. salina, D. magna, and $M$. macrocopa share the presence of particles of proteins, carbohydrates and cholesterol. The liquid part of the medium supplies mineral salts, trace elements, nucleic acid components, and watersoluble vitamins - nutrients which are needed in low concentration and are nontoxic when added in the relatively large excess required to compensate for the very poor efficiency of solutes ( 1 part of nutrients offered as particles is $40-60$ times more efficient than when offered as a solute).

Cholesterol, thiamine, riboflavin, pyridoxine, as well as nicotinic, pantothenic and folic acids are needed by all 3 species. The amphigonic Artemia salina also needs putrescine and biotin and not $\mathrm{B}_{12}$. Media for Daphnia magna and Moina macropoda 
are still rich in crudes (liver extract, serum, and egg yolk) making potential needs for these 3 vitamins undetectable. All 3 Crustacea need nucleic acid components; the optimal ratios and type of components vary for each species. Equally variable for the three crustaceans are the tolerances to protein/carbohydrate ratios.

The final medium (no. 100) for Artemia salina, a typical example of these media (Provasoli \& D'Agostino 1969), allows fertile adults for the amphigonic strain of A. salina but only advanced metanauplii for the parthenogenetic strain; its freshwater counterparts (Daphnia magna and Moina macropoda) complete at best 1 to 2 generations in similar media but with a different mineral base.

Incorporation of vitamins $\mathrm{E}$ and $\mathrm{D}$ in egg yolk and subsequent addition of this material to the media, allows only 5 to 6 generations in Daphnia magna and 50 generations in Moina macrocopa (continuing). Egg yolk alone is toxic; vitamin E might therefore be acting merely as antioxidant. Several antioxidants were tried, but depending on concentration, they were either inert or inhibitory.

Carotene, which is abundant in many Crustacea, is not needed in the present media. Egg yolk, because of its richness in fats and fatsoluble growth factors, blocked progress towards the identification of lipid fertility factors. After many trials we have now replaced egg yolk with a purified lipophilic protein which can bind almost its weight in fats. Current experiments are promising but we can neither yet state whether vitamin $\mathrm{E}$ and $\mathrm{D}$ are indispensible for Moina macrocopa, nor whether they represent the only lipid requirements.

\section{CONCLUSIONS}

Objection may be raised to presenting, at a symposium devoted to cultivation of marine organisms, results dealing mostly with freshwater crustaceans and generalizing from them. Some explanation may be in order.

The original reason for undertaking work on filter-feeding marine Crustacea was to define their importance in the food web. We had a good collection of phytoplankton organisms and therefore we thought this was a good time to attack the problem. No truly marine organism seemed satisfactory for intensive laboratory work based essentially on microbiological techniques. We admired the tenacity and the ingenuity displayed by MARShaLL \& ORR in prying out secrets of calanoid physiology, but we had neither their courage nor two shared lifetimes spent heroically. These deans of biological oceanography merit our admiration, any later progress starts from their pioneering.

Because of our self-imposed technical constraint, Artemia salina and Tigriopus japonicus were selected for their hardiness under environmental stress and availability. They served the immediate purpose. Preliminary experiments with osmotrophic media failed and it became necessary to develop phagotrophic artificial media.

Since Artemia salina is a hypersaline organism, a nagging thought recurred: Was the almost obligate phagotrophy in A. salina atypical? Was this organism forced to imbibe minimally to spare the expensive physiological work needed to keep its lymph almost 10 times more dilute than its environment? Would a freshwater organism 
faced with a less severe, opposite problem still be a phagotroph? Daphnia magna was therefore investigated and found to be similar to Artemia salina in its phagotrophic propensities.

Then problems of fertility emerged. Ever more complex media were tried. Addition of egg yolk enriched with vitamin D and $E$ allowed 5 to 6 generations of Daphnia magna in contrast to 1 to 2 generations allowed by the previous medium. The time consumed in preparing media in which lipid factors were available yet not toxic could be offset had we a fastgrowing organism. Moina macrocopa served that purpose: indefinite cultures opened the way to identifying some of the factors needed for fertility.

Since the nutritional similarities were found with a phyllopod, a harpacticoid and 2 copepods which live respectively in hypersaline, euryhaline and freshwater we feel that these similarities suggest a basic nutritional pattern perhaps common to most phytoplankton-feeding Crustacea.

The first part of this paper dealt with the phenomenon that several algae supported only a limited number of generations of the predator, and that addition to the medium of organic crude materials or vitamins made them adequate for an indefinite number of generations of the predator. Assuming that the effect of yeast and liver extracts on 2 Dunaliella species underlies a vitamin effect, how can we relate the addition of vitamins to the increased nutritional value for crustaceans of the algae so treated?

Since algae are notorious accumulators of all types of substances, the vitamin effect could simply be due to preferential uptake and accumulation of added vitamins. To be beneficial, then, a vitamin should be needed by the predator. Since vitamin $B_{12}$ increased fertility but was not needed either by algae or Dapbnia magna, $B_{12}$ may induce changes in algal metabolism and cell composition.

The algal flagellate Neocbloris alveolaris does need $\mathrm{B}_{12}$; growth is not enhanced by $B_{12}$, but the cells become greener within 18 hrs. Analysis showed that $B_{12}$ caused decrease of the free amino-acid pool while protein nitrogen increased; all indications pointed to channeling of these proteins into chloroplast synthesis (EAsLEy 1969). Similarly interesting are the results of FORD \& GOULDEN (1959) on Ocbromonas malbamensis, a freshwater chrysomonad which needs $\mathrm{B}_{12}$. They found that when $\mathrm{B}_{12}$ is minimal the cell content in protein, fats and vitamins is much higher in cells grown in mineral media in the light than in cells grown in darkness on rich organic media. Increases in vitamin $B_{12}$, in light and darkness, augment the content in proteins, RNA, nicotinic and pantothenic acids and riboflavin while decreasing substantially the content in lipids and the vitamin $B_{6}$ complex. It is also significant that, in limiting $B_{12}$, the dark grown cells leaked substantial amounts of vitamins into the medium. Similar changes in metabolism, excretion, and cell composition may have occurred in our experiments with organic enrichments.

The second part of our paper was concerned with the participation of fats in enhancing the fertility of Daphnia magna and Moina macrocopa. The role of vitamin $\mathrm{E}$ in repairing ovarian disfunction and restoring fertility in $D$. magna was reported long ago (VIEHOEVER \& COHEN 1938); even though their experimentation was limited, the results seem reliable. In an elegant research, vitamin $\mathrm{E}$ was shown to be the factor 
in dried grass responsible for initiating the transition from parthenogenetic to sexual reproduction in the rotifer Asplanchna (GILBERT \& THOMpson 1968). Ergosterol + olive oil (1:1 ratio) were reported to replace almost entirely the effect of yeast fatextractives in eliciting a $30 \%$ male progeny in Moina rectirostris (vON DEHN 1955); ephyppial egg production was related to ergosterol content. Incidentally, a few Moina macrocopa males are found in our artificial media and their proportion seems to vary with variations in the medium. The media are too complex to attribute specific effects to any one component.

Among insects, phytophagous species are the only ones known to require fatty acids for growth to adults; since none of these has been grown in continuous culture we do not know whether they need fertility factors, but a parasitic fly needs vitamin E for reproduction (House 1966).

As the work on crustacean nutrition progresses, parallels with insects are emerging such as the need for cholesterol, nucleic acid components, and for the same B vitamins; even putrescine, the need for which was reported first for Artemia salina (Provasoli \& D'Agostino 1962) is required by an insect (Davis 1966).

While a logical connection between the 2 parts of our work is still remote, our results suggest some new ways to improve rearing of marine invertebrates. An important step is to match as closely as possible the nutritional needs of the predator with the composition of the prey. Variety in diet helps, but more algal species have to be tested as well as other microorganisms.

Since a vitamin enrichment seems useful in increasing the nutritive value of the algae, deliberate use of marine bacteria which overproduce vitamins (BURKHOLDER 1963) seems advisable as well as isolation of bacteria and yeasts from particularly successful crude cultures of invertebrates. Sugars to favour their growth should be used sparingly $(1-20 \mathrm{mg} \%)$ to balance bacterial growth with predator consumption. Unfortunately, many marine bacteria acidify seawater and reduce free oxygen; both activities are unfavorable to most marine invertebrates. Efforts should be made to isolate bacteria which utilize carbohydrates completely (non-acidifiers), use nitrate or urea and need few if any vitamins. Often, addition of nutrients for bacteria is not needed. The products of excretion of algae and invertebrates may suffice, creating a balanced microcosm.

Use of antibiotics can be avoided; deliberate, repeated inoculation of desirable bacteria may replace the flora and achieve a beneficial change. Control of bacteria can be obtained by introducing phagotrophic colorless flagellates such as Monas which often have the right size to be ingested and are well digested. Mass cultivation of oyster larvae was ingeniously based on such an artificial food chain by IMAI et al. (1950).

If algae are employed as food, it is advisable to enrich seawater with $\mathrm{NO}_{3}, \mathrm{PO}_{4}$ and if necessary, vitamins, so as to balance algal growth with predator consumption. Several enrichments have been described (GuILLARd \& RYTHER 1962, von STOSCH 1964, Provasoli 1968). Light of suitable photoperiodicity is essential for "normal" algal metabolism, insuring a more stable cell composition and thus, repeatability. Lacking the enrichment, periodic addition of food algae is necessary - a timeconsuming, often unreliable practice. Age of the algal cultures, media and conditions 
of their growth, all may elicit wide differences in algal cell composition: the species may be the same, but the nutritional value different.

When no other information is available it is useful to mimic the natural conditions as far as possible. Filter-feeding species which have several yearly generations are likely to be versatile in food requirements: they grow well in nature on everchanging food. Organisms which reproduce once a year are subjected to wide fluctuations in quality and quantity of food and to periods of starvation before they reproduce. Are these nutritional events only something that these species have become accustomed to, or are they needed? In other words, do different stages of the predator need a specific seasonal food? This possibility is worth investigation. If true, this might be the key to culturing some species and we could shorten their life cycle to a few months.

The few analyses of phytoplankton composition may be misleading in their homogeneity (PArsons et al. 1961) such analyses (total protein, fat and carbohydrate) are of little utility for nutritional guidance and mask well known heterogeneities (pigments, reserves, vitamins, quality and ratios of components). Conceivably, even periods of ostensible plenty (abundant phytoplankton) may lack a vital factor. Adequate stores of energy sources quite likely help bridge this period of nutritional imbalance. Deficiencies of nutrients in artifical media, especially vitamins, rather than killing Artemia salina, arrest growth at a certain stage (D'Agostino \& Provasoli unpublished) but may permit long survival (1-2 months, a long period for an organism which, with the right food, can complete its life cycle in 10-15 days). When adulthood and procreation occur at a certain season, does this mean that the typical food organisms are then especially rich in growth and fertility factors?

\section{SUMMARY}

1. Fertility stops after a few aseptic generations in cultures of Artemia salina, Tigriopus japonicus and Daphnia magna fed algae.

2. Fertility was restored in amphigonic and parthenogenetic Artemia salina subjected to low-salinity stress by addition of milligram concentrations of yeast and liver extract.

3. Fertility of Tigriopus japonicus and Dapbnia magna was restored by addition of vitamin mixtures to the algae/crustacean medium.

4. The vitamins act directly on the algae by increasing their nutritional value for the crustaceans cultivated.

5. Continuous aseptic culture of Moina macrocopa was obtained in an artifical medium enriched with egg yolk and vitamins $E$ and D. Such a medium supports only 5 to 6 generations of Daphnia magna.

6. Lipid factors seem essential for sustained fertility in Moina macrocopa and Daphnia magna.

7. Some suggestions are made for improving partially gnotobiotic cultures of filterfeeders. 


\section{LITERATURE CITED}

BURKHOLDER, P. R., 1963. Some nutritional relationship among microbes of sea sediments and waters. In: Symposium on marine microbiology. Ed. by C. H. Oppenheimer, Thomas, Springfield, Illinois, 133-150.

Burns, C. W., 1968. The relationship between body size of filter-feeding Cladocera and the maximum size of particle ingested. Limnol. Oceanogr. 13, 675-678.

CoRkETT, C. J., 1968. La reproduction en laboratoire des copépodes marins Acartia clausi Giesbrecht et Idya furcata (Barro). Pelagos 10, 77-90.

D'Agostino, A. S. \& Provasoly, L., 1968. Effects of salinity and nutrients on mono- and diaxenic cultures of two strains of Artemia salina. Biol. Bull. mar. biol. Lab., Woods Hole 134, 1-14.

Davis, G. R. F., 1966. Growth and development of prairie grain worm Ctenicera destructor Brown (Coleoptera: Elateridae), on synthetic diets. Can. J. Zool. 44, 995-1001.

DeHn, M. v., 1955. Die Geschlechtsbestimmung der Daphniden. Die Bedeutung der Fettstoffe untersucht an Moina rectirostris L. Zool. Jb. Abt. allg. Zool. Physiol. Tiere. 65, 334-356.

Dewey, J. E. \& PARKER, B. L., 1964. Mass rearing of Daphnia magna for insecticide bioassay. J. econ. Ent. 57, 821-825.

Droor, M. R., 1966. The role of algae in the nutrition of Heteramoeba clara Droop, with notes on Oxyrrhis marina Dujardin and Philodina roseola EHRENBErg. In: Some contemporary studies in marine science. Ed. by H. Barnes. Allen \& Unwin, London, 269-282.

EASLEY, L. W., 1969. Modification of protein synthesis by vitamin $B_{12}$ in the marine algal flagellate Neocbloris pseudoalveolaris. J. Protozool. 16, 286-289.

Ford, J. E. \& Goulden, J. D. S., 1959. The influence of vitamin $B_{12}$ on growth rate and cell compositions of the flagellate Ocbromonas malbamensis. J. gen. Microbiol. 20, 267-270.

GiBor, A., 1956. Some ecological relationship between phyto- and zooplankton. Biol. Bull. mar. biol. Lab., Woods Hole 111, 230-234.

Gilbert, J. J. \& Thompson, G. A., 1968. Alpha tocopherol control of polymorphism in the rotifer Asplanchna. Science, N.Y. 159, 734-736.

Guillard, R. R. L. \& RYTher, J. H., 1962. Studies on marine planktonic diatoms. I. Cyclotella nana Hustedt and Detonula confervacea (Cleve) Gran. Can. J. Microbiol. 8, 220-239.

House, H. L., 1966. Effects of vitamins $\mathrm{E}$ and $\mathrm{A}$ on growth and development and the necessity of vitamin E for reproduction in the parasitoid Agria affinis (FAllen) (Diptera, Sarcophagidae). J. Insect Pbysiol. 12, 409-417.

Imai, T., Hatanaka, M., Sato, R., Sakai, S. \& Yuki, R., 1950. Artificial breeding of oysters in tanks. Toboku J, agric. 1, 69-86.

Lefèvre, M., 1942. L'utilization des algues d'eau douce par les Cladocères. Bull. biol. Fr. Belg. 76, 250-276.

McMahon, J. W. \& Rigler, F. H., 1963. Mechanisms regulating the feeding rate of Daphnia magna Straus. Can. J. Zool. 41, 321-332.

Marshale, S. M. \& OrR, A. P., 1955. On the biology of Calanus finmarchicus. VIII. Food uprake, assimilation and excretion in adult and stage $V$ Calanus. J. mar. biol. Ass. $U . K$. $34,495-530$.

MOYsE, J., 1963. A comparison of the value of various flagellates and diatoms as food for barnacle larvae. J. Cons. int. Explor. Mer, 28, 175-187.

NeEdlek, A. B., 1949. Paralytic shellfish poisoning and Gonyaulax tamarensis. J. Fish. Res. Bd Can. 7, 490-504.

Parsons, T. R., Stephens, K. \& Strickland, J. D. H., 1961. On the chemical composition of eleven species of marine phytoplankters. J. Fish. Res. Bd Can. 18, 1001-1016,

Provasoli, L., 1968. Media and prospects for the cultivation of marine algae. In: Cultures and collections of algae. Ed. by A. Watanabe \& A. Hattori. Proc. U.S. - Japan Conf. Hakone, Sept. 1966. Jap. Soc. Plant Physiol., 63-75.

- \& D'Agostrno, A. S., 1962. Vitamin requirements of Artemia salina in aseptic culture. Am. Zool. 2 (3), Abstr. 12. 
- - 1969. Development of artificial media for Artemia salina. Biol. Bull. mar. biol. Lab., Woods Hole 136, 434-453.

- \& PINTNER, I. J., 1953. Ecological implications of in vitro nutritional requirements of algal flagellates. Ann. N.Y. Acad. Sci. 56, 839-851.

- ShIRAishi, K. \& LANCE, J. R., 1959. Nutritional idiosyncrasies of Artemia and Tigriopus in monaxenic culture. Ann. N.Y, Acad. Sci. 77, 250-261.

Reeve, M. R., 1963. The filter-feeding of Artemia. I. In pure cultures of plant cells. J. exp. Biol. 40, 195-205.

Shiraishi, K. \& Provasoli, L., 1959. Growth factors as supplement to inadequate algal food for Tigriopus japonicus. Toboku J. agric. Res. 10, 89-96.

Sтолсн, H. A. von, 1964. Wirkungen von Jod und Arsenit auf Meeresalgen in Kultur. Int. Seaweed Symp. 4 (Biarritz), 142-150.

TAUB, F. B. \& Dollar, A. M., 1968. The nutritional inadequacy of Chlorella and Chlamydomonas as food for Daphnia pulex. Limnol. Oceanogr. 13, 607-617.

Viehoever, A. \& Cohen, J., 1938. The response of Daphnia magna to vitamin E. Am. J. Pharm. 110, 297-315.

Wesson, L. G., 1932. A modification of the Osborne-Mendel salt mixture containing only inorganic constituents. Science, N.Y, 75, 339-340.

Zulioux, E. J. \& WrLson, D. F., 1966. Culture of a planktonic calanoid copepod through multiple generations. Science, N.Y. 151, 996-998.

First author's address: Dr. L. Provasoli

Haskins Laboratories

165 Prospect Street

New Haven, Conn. 06520, USA 